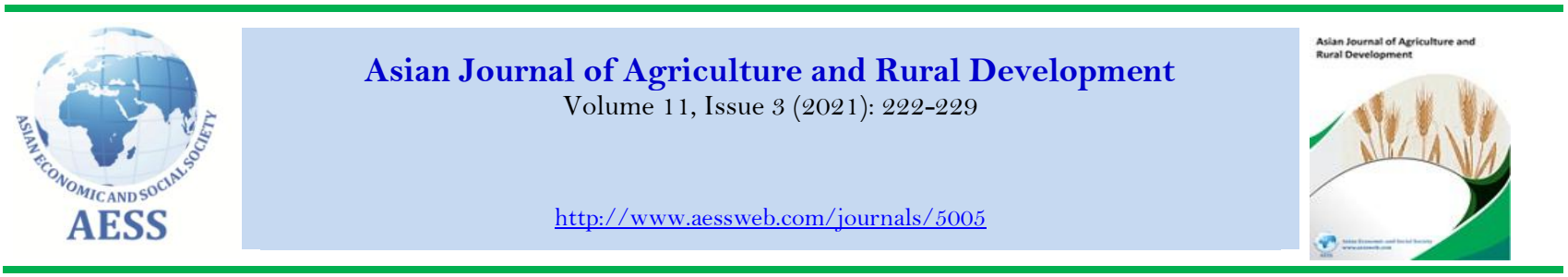

\title{
MARKET-BASED STRATEGY TO ANTICIPATE COVID-19 PANDEMIC IN SMALLHOLDER RUBBER PLANTATIONS IN RIAU PROVINCE, INDONESIA
}

\author{
Shorea Khaswarina ${ }^{\text {q }}$ \\ Sucherly \\ Umi Kaltumc \\ R. Rina Novianti Ariawaty
}

\begin{tabular}{l}
\hline Article History \\
\hline Received: 20 May 2021 \\
Revised: 25 June 2021 \\
Accepted: 27 July 2021 \\
Published: 23 August 2021
\end{tabular}

\section{Keywords}

Rubber

Market strategy

Marketing mix strategy

Customer value

Marketing performance.

\author{
a,b,sd Doctoral Study Program of Management Sciences Faculty of Economics and \\ Business, University of Padjadjaran Dipatiukur, Bandung, Indonesia. \\ $\triangle$ shorea.khaswarina@yahoo.com (Corresponding author)
}

\begin{abstract}
The coronavirus pandemic had disrupted almost all businesses in various sectors, one of which is the plantation sector. Smallholder rubber plantations in Riau Province, Indonesia have faced the very tough challenges of the coronavirus pandemic. Efforts that could be made were marketing rubber products by implementing market-based strategies, namely market strategy, marketing mix strategy, customer value and marketing performance. This study aimed to analyze the effects of market strategy, marketing mix strategy, and customer value on marketing performance in smallholder rubber plantations in Riau Province during the Covid-19 pandemic. Data collection was carried out using 45 respondents as heads of smallholder rubber plantation farmer groups in Riau Province. Data analysis used structural equation modeling-partial least square (SEM-PLS). The results show that market strategy and marketing mix strategy had a significant direct effect on customer value. Customer value had a significant direct effect on the marketing performance of smallholder rubber plantation farmer groups in Riau, while the market and marketing mix strategies had an indirect effect.
\end{abstract}

Contribution/Originality: This study contributes to the existing literature on market-based strategy. It requires knowledge of appropriate market-based strategies to be implemented in order to attract as many consumers as possible. The study findings will be used to improve rubber marketing performance.

DOI: $10.18488 /$ journal.ajard.2021.113.222.229

$\operatorname{ISSN}(\mathrm{P}):$ 2304-1455/ ISSN(E): 2224-4433

How to cite: Shorea Khaswarina --- Sucherly --- Umi Kaltum --- R. Rina Novianti Ariawaty (2021). Market-Based Strategy to Anticipate Covid-19 Pandemic in Smallholder Rubber Plantations in Riau Province, Indonesia. Asian Journal of Agriculture and Rural Development, 11(3), 222-229. 10.18488/journal.ajard.2021.113.222.229 (C) 2021 Asian Economic and Social Society. All rights reserved.

\section{INTRODUCTION}

The Covid-19 pandemic has disrupted economies in many sectors around the world. Reduced demand will lead to a reduction in overall profit, particularly in less influential sectors (Guerrieri, Lorenzoni, Straub, \& Werning, 2020) such as the rubber plantation sector.

Rubber plantations are the main global source of natural rubber production; natural rubber is as an important raw material in several high-level manufacturing sectors. Different rubber plantations around the world have different plant characteristics and quality of latex (Brenas, 2019) affecting the price of rubber. According to Su, Liu, Tao, and Lobonţ (2019), rubber prices can change over the long or short term. Short-term changes are usually influenced by world natural rubber production and changes in world rubber consumption, while long-term changes are influenced by changes in natural rubber stocks, production, and consumption.

The institutional existence of smallholder rubber plantations in Riau by implementing direct market-based marketing strategies is used as a solution to overcome farmers' low bargaining positions. This community rubber 
plantation institution is the Kuantan Singingi Rubber Association (Apkarkusi), which consists of 45 farmer groups who conducts business activities that focus on selling products to other companies, not to individual consumers. This means that all farmer groups are Business to Business (B2B) companies. Das, Deshpande, Salvi, Goyal, and Bhirud (2018) suggest that B2B marketing focuses on meeting business needs rather than non-individual corporate consumers, which makes it a complex business system. A B2B business strategy involves a real business information campaign about a product or service.

Rubber farmer groups in Riau Province during the Covid-19 pandemic are facing marketing problems. In particular, the minimal application of market-based strategies is a major concern. The facts found in Riau reveal that although the auction system has been implemented in the marketing activities of farmer groups, some continue to do marketing through traditional mechanisms. The reason is that the farmer groups do not have a factory for processing rubber, which leads suppliers to employ services from collectors to distribute their products to factories. The location of the farmers' fields, which are far from the factory, causes both production and distribution costs. These problems can be overcome by implementing a market and marketing mix strategies. The application of the marketing mix strategy uses the new era $4 \mathrm{v}$ marketing theory (differentiation, functional, value-added, and resonance), which provides a reference for marketing agricultural products. Meanwhile, the application of market strategy is a formation strategy that includes customer involvement and technology leadership.

A market strategy is a plan for how the company will provide value to the target market and make profits by fulfilling a promise/demand. The strategy identifies target market customers, creates a value proposition for each customer groups, and identifies the optimal channel for successfully providing a product or service to the target market (Shimasaki, 2014). According to Brege and Kindström (2019), market strategy is used to refer to the company's strategy in creating and delivering customer value. A proactive producer will gain competitive advantage by having a superior understanding of the customer. Proactive, in the context of $\mathrm{B} 2 \mathrm{~B}$ marketing, refers to companies that are future-oriented, take initiative, and drive change (Grant \& Ashford, 2008; Kindström, Ottosson, \& Carlborg, 2018; Parker, Bindl, \& Strauss, 2010).

A proactive formation strategy refers to a company's strategy to affect customers, suppliers, and other market players in order to strengthen their own ability to provide superior customer value and reduce the ability of their competitors, thereby gaining competitive advantage (Elg, Deligonul, Ghauri, Danis, \& Tarnovskaya, 2012; Kindström et al., 2018; Storbacka \& Nenonen, 2015). The strength of a market formation strategy comes from a combination of proactive activities aimed at changing market structure and customer-focused activities that provide companies with in-depth insights into current and potential customer needs (Brege and Kindström (2019)). Exploring market strategies and related activities is important, because proactivity has the potential to increase the B2B performance (Kindström et al., 2018; Narver, Slater, \& MacLachlan, 2004).

The marketing mix has gradually changed from the original manufacturer-oriented 4p theory (product, price, place, and promotion) to the $4 \mathrm{v}$ theory, which focuses on customer satisfaction. In recent years, the marketing mix has once again evolved into a $4 \mathrm{v}$ theory centered on customer loyalty. The agricultural product marketing mix is an agricultural product marketing strategy that flexibly uses the $4 \mathrm{v}$ combination theory, which can play a positive role in the development of agricultural products.

Deng, He, Fu, Liu, and $\mathrm{Hu}$ (2019) developed the $4 \mathrm{v}$ combination theory into the marketing of agricultural products and studied the impact of the $4 \mathrm{v}$ marketing mix on the perceived value of agricultural products. This provides new ideas and strategic support for marketing agricultural products in China. The four elements of the $4 \mathrm{v}$ marketing theory, namely differentiation, functional flexibility, added value, and resonance to the perceived value.

The application of marketing strategy theory is important in influencing consumers to purchase a product or service, and is often referred to as the marketing mix (Kotler \& Armstrong, 2018). Market strategy refers to the company's strategy in creating and delivering customer value. Proactive, in the context of B2B marketing, refers to companies that are future-oriented, take initiative, and drive change (Brege \& Kindström, 2019). Therefore, it requires knowledge of appropriate market-based strategies to be implemented in order to attract as many consumers as possible, so that farmer groups will become proactive producers and have a superior understanding of customers so as to obtain maximum profit. This research aimed to analyze the applicability of market-based strategies on smallholder rubber plantations in Riau Province facing the Covid-19 pandemic effects, by analyzing the influence of market strategies, marketing mix strategies, and customer value on marketing performance.

\section{MATERIALS AND METHODS}

The method used was the verification method: namely, measuring and testing the causal relationships between the variables of customer value, market strategy, and marketing mix strategy. The unit of research analysis was farmer groups in Riau Province, Indonesia. The sampling technique was the saturated sampling technique. The research observation unit was the head of the farmer group. Data analysis used structural equation modeling-partial least square (SEM-PLS). SEM-PLS analysis consists of two models, the structural model/inner model (Figure 1) and the measurement model/outer model (Table 1). 


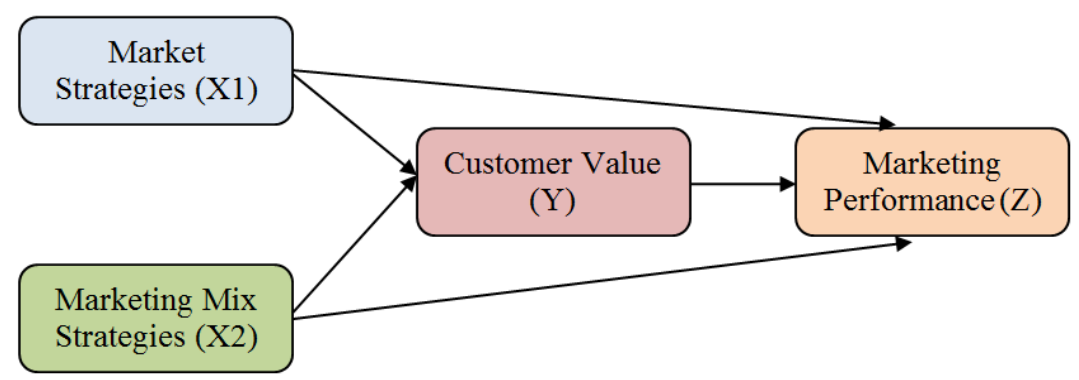

Figure-1. Structural model.

Table-1. Measurement model.

\begin{tabular}{|c|c|c|c|}
\hline Latent variables & Dimensions & Manifest variables & Symbol \\
\hline \multirow[t]{33}{*}{$\begin{array}{l}\text { Market strategies } \\
(\mathrm{X} 1)\end{array}$} & \multirow[t]{10}{*}{$\begin{array}{l}\text { Market } \\
\text { formation }\end{array}$} & $\begin{array}{l}\text { The ability of farmer groups to increase the number of } \\
\text { rubber customers }\end{array}$ & $\mathrm{X} 1.01$ \\
\hline & & $\begin{array}{l}\text { Rules for the number of processed rubber materials } \\
\text { sold to customers }\end{array}$ & $\mathrm{X} 1.02$ \\
\hline & & $\begin{array}{l}\text { The farmer group knows the price of rubber before it is } \\
\text { sold to customers }\end{array}$ & $\mathrm{X} 1.03$ \\
\hline & & $\begin{array}{l}\text { Target sales volume for processed rubber materials of } \\
\text { farmers }\end{array}$ & $\mathrm{X} 1.04$ \\
\hline & & $\begin{array}{l}\text { The rate of each processed rubber materials sales } \\
\text { volume increases }\end{array}$ & $\mathrm{X} 1.05$ \\
\hline & & Determinant factors of supplier-customer agreements & $\mathrm{X} 1.08$ \\
\hline & & $\begin{array}{l}\text { The farmer sells the processed rubber materials } \\
\text { according to the existing agreement }\end{array}$ & $\mathrm{X} 1.09$ \\
\hline & & $\begin{array}{l}\text { Process the rubber materials and use the sap vinegar } \\
\text { according to the provisions }\end{array}$ & $\mathrm{X} 1.12$ \\
\hline & & $\begin{array}{l}\text { Technological knowledge of farmers in the rubber } \\
\text { business }\end{array}$ & $\mathrm{X} 1.13$ \\
\hline & & $\begin{array}{l}\text { Discussion of new technology between farmer-land } \\
\text { owners }\end{array}$ & $\mathrm{X} 1.15$ \\
\hline & \multirow{12}{*}{$\begin{array}{l}\text { Customer } \\
\text { engagement }\end{array}$} & Ability to build farmer-customer relationships & $\mathrm{X} 1.16$ \\
\hline & & Providing services to customers & $\mathrm{X} 1.17$ \\
\hline & & $\begin{array}{l}\text { The tendency of customers to buy processed rubber } \\
\text { materials from farmers }\end{array}$ & $\mathrm{X} 1.18$ \\
\hline & & How many times customers have subscribed & $\mathrm{X} 1.19$ \\
\hline & & Involvement of family members in the rubber business & $\mathrm{X} 1.20$ \\
\hline & & The grade of processed rubber materials & $\mathrm{X} 1.21$ \\
\hline & & $\begin{array}{l}\text { Rules for the duties of suppliers in the } \\
\text { family/village/hamlet }\end{array}$ & $\mathrm{X} 1.22$ \\
\hline & & The motivation of farmers to do rubber business & $\mathrm{X} 1.24$ \\
\hline & & The level of maintaining the rubber business & $\mathrm{X} 1.27$ \\
\hline & & The decision to do rubber business & $\mathrm{X} 1.28$ \\
\hline & & The decision to sell rubber products to customers & $\mathrm{X} 1.29$ \\
\hline & & $\begin{array}{l}\text { The ability of farmer groups to continue to innovate } \\
\text { due to customer involvement }\end{array}$ & $\mathrm{X} 1.30$ \\
\hline & \multirow{11}{*}{$\begin{array}{l}\text { Technology } \\
\text { leadership }\end{array}$} & Determine the use of technology & $\mathrm{X} 1.31$ \\
\hline & & Adopting new things in business & $\mathrm{X} 1.32$ \\
\hline & & Who is adopting new things? & $\mathrm{X} 1.33$ \\
\hline & & Have attended extension & $\mathrm{X} 1.35$ \\
\hline & & New ways/methods in the rubber business & $\mathrm{X} 1.36$ \\
\hline & & New ways of saving production costs & $\mathrm{X} 1.37$ \\
\hline & & Special tools for notching & $\mathrm{X} 1.38$ \\
\hline & & $\begin{array}{l}\text { Mobile phone/social media for communication with } \\
\text { customers }\end{array}$ & $\mathrm{X} 1.39$ \\
\hline & & Using the internet to determine the price of rubber & $\mathrm{X} 1.40$ \\
\hline & & Benefits of guidance/extension from related offices & $\mathrm{X} 1.41$ \\
\hline & & $\begin{array}{l}\text { Benefits of technology in the business and buying and } \\
\text { selling of rubber }\end{array}$ & $\mathrm{X} 1.44$ \\
\hline \multirow[t]{2}{*}{$\begin{array}{l}\text { Marketing mix } \\
\text { strategies (X2) }\end{array}$} & \multirow{2}{*}{$\begin{array}{l}\text { Differentiation } \\
\text { of agricultural } \\
\text { products }\end{array}$} & $\begin{array}{l}\text { Performance of farmer groups is already good in } \\
\text { producing rubber materials }\end{array}$ & $\mathrm{X} 2.01$ \\
\hline & & The quality of the processed rubber materials is in & $\mathrm{X} 2.03$ \\
\hline
\end{tabular}




\begin{tabular}{|c|c|c|c|}
\hline Latent variables & Dimensions & Manifest variables & Symbol \\
\hline & & accordance with the national standard quality & \\
\hline & & The resulting rubber form lump/latex & $\mathrm{X} 2.04$ \\
\hline & & Processing rubber latex, before being marketed & $\mathrm{X} 2.05$ \\
\hline & & $\begin{array}{l}\text { Processed rubber materials can last before being } \\
\text { processed by customers }\end{array}$ & $\mathrm{X} 2.06$ \\
\hline & & $\begin{array}{l}\text { The quality of the processed rubber materials is as } \\
\text { promised }\end{array}$ & $\mathrm{X} 2.07$ \\
\hline & & Ability to produce processed rubber materials & X2.09 \\
\hline & & The resistance level of the processed rubber materials & $\mathrm{X} 2.10$ \\
\hline & & $\begin{array}{l}\text { The peculiarities of natural/rubber products are } \\
\text { difficult to imitate or replace }\end{array}$ & $\mathrm{X} 2.12$ \\
\hline & & $\begin{array}{l}\text { The shape and quality of the processed rubber } \\
\text { materials product are easy to improve }\end{array}$ & $\mathrm{X} 2.14$ \\
\hline & & $\begin{array}{l}\text { Time to improve the quality of processed rubber } \\
\text { materials in the old factory }\end{array}$ & $\mathrm{X} 2.15$ \\
\hline & \multirow{3}{*}{$\begin{array}{l}\text { Agricultural } \\
\text { product } \\
\text { elasticity }\end{array}$} & $\begin{array}{l}\text { The function of rubber products according to the needs } \\
\text { of the target market }\end{array}$ & $\mathrm{X} 2.16$ \\
\hline & & $\begin{array}{l}\text { Customers are easy to get processed rubber materials } \\
\text { products }\end{array}$ & $\mathrm{X} 2.17$ \\
\hline & & Affordability of rubber prices by customers & $\mathrm{X} 2.19$ \\
\hline & \multirow[t]{4}{*}{ Value-added } & The process of extraction of rubber latex is hereditary & $\mathrm{X} 2.20$ \\
\hline & & $\begin{array}{l}\text { Prices increase due to the use of technology to process } \\
\text { processed rubber materials }\end{array}$ & $\mathrm{X} 2.21$ \\
\hline & & $\begin{array}{l}\text { The target market is achieved by means of a marketing } \\
\text { channel }\end{array}$ & $\mathrm{X} 2.22$ \\
\hline & & $\begin{array}{l}\text { The price of the processed rubber materials goes up } \\
\text { with a special price service }\end{array}$ & $\mathrm{X} 2.23$ \\
\hline \multirow{15}{*}{$\begin{array}{l}\text { Customer Value } \\
\text { (Y) }\end{array}$} & \multirow[t]{4}{*}{ Resonance } & The frequency of extraction of rubber latex & $\mathrm{X} 2.24$ \\
\hline & & Time to collect processed rubber materials & $\mathrm{X} 2.25$ \\
\hline & & Good relationship/trust/communication & $\mathrm{X} 2.26$ \\
\hline & & $\begin{array}{l}\text { How farmers deliver processed rubber materials to } \\
\text { customers }\end{array}$ & $\mathrm{X} 2.27$ \\
\hline & \multirow[t]{2}{*}{ Emotional value } & Farmers are satisfied in selling to customers & Y.01 \\
\hline & & Farmers believe in selling to customers & Y.02 \\
\hline & \multirow[t]{2}{*}{ Social value } & $\begin{array}{l}\begin{array}{l}\text { Reasons for selling processed rubber materials to } \\
\text { customers }\end{array} \\
\end{array}$ & Y.03 \\
\hline & & Farmers have relationships with customers & Y.04 \\
\hline & \multirow[t]{2}{*}{ Quality value } & $\begin{array}{l}\begin{array}{l}\text { Processed rubber materials quality performance } \\
\text { conditions }\end{array} \\
\end{array}$ & Y.05 \\
\hline & & Farmers are able to provide services quickly & Y.07 \\
\hline & \multirow[t]{5}{*}{ Cost/price value } & $\begin{array}{l}\text { The selling price of the processed rubber materials is as } \\
\text { expected }\end{array}$ & Y.08 \\
\hline & & When do prices go up and down? & Y.09 \\
\hline & & Prices are appropriate to meet customer needs & Y.11 \\
\hline & & Prices are set by farmers/suppliers & Y.12 \\
\hline & & Prices according to meet needs & Y.13 \\
\hline \multirow{7}{*}{$\begin{array}{l}\text { Marketing } \\
\text { performance }(Z)\end{array}$} & \multirow[t]{3}{*}{ Sales value } & Sales value increases every year & Z.01 \\
\hline & & Sales value is always achieved & Z.02 \\
\hline & & Sales volume targets are always achieved & Z.04 \\
\hline & \multirow{2}{*}{$\begin{array}{l}\text { Customer } \\
\text { growth }\end{array}$} & The number of consumers is fixed at each harvest & Z.05 \\
\hline & & $\begin{array}{l}\text { The target number of customers has always been } \\
\text { achieved }\end{array}$ & Z.06 \\
\hline & \multirow[t]{2}{*}{$\begin{array}{l}\text { Productivity } \\
\text { growth }\end{array}$} & $\begin{array}{l}\text { Total sales of all products with total product sales } \\
\text { increased }\end{array}$ & Z.07 \\
\hline & & Profits increase with each sale & Z.08 \\
\hline
\end{tabular}

From the Smart-PLS output we can show the effect between one latent variable and another by looking at the $P$ value: if $P \leq 0.05$, the latent variable had a significant effect on other latent variables. Conversely, if $P>0.05$, the latent variable did not have a significant effect on other latent variables (Saptutyningsih \& Esty, 2020). The magnitude of the effect can be seen from the coefficient value. 


\section{RESULTS AND DISCUSSION}

\subsection{Direct Effect of Market and Marketing Mix Strategies on Customer Value}

The direct effect of market and marketing mix strategies on customer value is shown in Table 2.

Table-2. Direct effect of market and marketing mix strategies on customer value.

\begin{tabular}{l|c|c|c|c|c}
\hline Hypothesis & $\begin{array}{c}\text { Path } \\
\text { coefficient }\end{array}$ & $\begin{array}{c}\text { Standard } \\
\text { deviation }\end{array}$ & $\begin{array}{c}\boldsymbol{t} \text { - } \\
\text { statistic }\end{array}$ & $\boldsymbol{P}$ value & $\boldsymbol{r}^{\mathbf{2}}$ \\
\hline Market strategy -> customer value & 0.424 & 0.122 & 3.480 & 0.001 & 0.577 \\
\hline Marketing mix strategy $->$ customer value & 0.389 & 0.126 & 3.083 & 0.002 & \\
\hline
\end{tabular}

\subsection{Direct Effect of Market Strategy on Customer Value}

Table 2 shows that the $P$ value of market strategy was lower than alpha $5 \%(0.001<0.05)$, which means that market strategy had a significant effect on customer value. The path coefficient value was positive, namely 0.424 , which means that each increase in market strategy by one point would increase customer value by 0.424 units and vice versa, assuming other variables remain constant. The more relevant the market strategy used, the better the benefits that will be obtained from the products of the farmer group, namely processed rubber materials that must be paid for by customers. The research shows that the better or the higher the market strategy in the process level of the processed rubber materials price agreement, the higher the customer value. Based on the indicator of the level of the processed rubber materials price agreement process from the market formation dimension, the price formation rules were based on the condition of the dollar exchange rate, SICOM rubber, and the condition of the quality/quality of the processed rubber materials in the field, which could also affect the price offered. These rules or conditions have been approved by the company of the buyer who wants to join by making a statement letter that they were willing to follow the provisions related to the mechanism to be determined in the marketing of the processed rubber materials auction. That way the level of trust between farmers and customers became stronger. This research also shows that in the marketing of the auction system of the customer (factory) that offered the highest price would get all the farmer groups' processed rubber materials. This provides a higher profit compared to selling to collector traders and guarantees that all of the farmers' rubber products were sold if they met the standard. According to Bhanot, Kathuria, and Das (2020), choosing to sell through alternative marketing channels helped farmers to minimize losses and avoid difficulties in sales. Islam, Hollebeek, Rahman, Khan, and Rasool (2019) stated that service quality had a positive effect on customer involvement. The customer involvement strategy was one of the dimensions of market strategy related to customer value, because it focused on activities aimed at providing higher customer value through a superior understanding of their needs, including latent needs, and developing offerings to meet those needs.

\subsection{Direct Effect of Marketing Mix Strategy on Customer Value}

Table 2 shows that the $P$ value of the marketing mix strategy was smaller than $5 \%$ alpha $(0.002<0.05)$, meaning that the marketing mix strategy had a significant effect on customer value. The path coefficient value (0.389) was positive, meaning that each 1-point increase in the marketing mix strategy would increase the customer value by 0.389 units and vice versa, assuming other variables remain constant. The higher the marketing mix strategy in the form of rubber produced (lump/latex), the higher the customer value. Based on the indicators of the form of rubber produced (lump/latex) from the dimensions of agricultural product differentiation, all rubber produced by farmers was in lump form so that it was in accordance with customer/factory demand. According to Purohit, Paul, and Mishra (2021), product is a major concern and it is important to acknowledge the customer's perspective when developing it. The results show that the shape of the processed rubber materials produced by lump/latex methods contributed to increasing the marketing mix strategy, because the shape of the processed rubber materials produced was in accordance with consumer demands.

Based on the indicator of the affordability of the location by customers from the elasticity dimension of agricultural products, the reach of the location of rubber products by customers would lead to a sense of satisfaction so that customer value increased. Purohit et al. (2021) argued that companies must be careful when deciding on distribution channels to ensure that a product or service is available. According to Ranta, Keränen, and AarikkaStenroos (2019), services that allowed products and materials to maintain value for longer increase the value creation potential of a single product.

Based on the indicators of hereditary rubber sap extraction process from the added value dimension, hereditary extraction could improve the marketing mix strategy to support added value and increase customer value. Kwok, Tang, and $\mathrm{Yu}$ (2020) suggest that marketing mix is a dominant factor in identifying market developments and trends, and was the main tool in achieving the company's business goals. Marketing activities consisted of elements of the marketing mix that reflected customer expectations and involved all factors used by companies to affect consumer perceptions of their products and services.

\subsection{Effect of Market and Marketing Mix Strategies and Customer Value on Marketing Performance}

The direct effect of market and marketing mix strategies and customer value on marketing performance is shown in Table 3. 
Table-3. Direct effect of market and marketing mix strategies and customer value on marketing performance.

\begin{tabular}{|c|c|c|c|c|c|}
\hline Hypothesis & $\begin{array}{c}\text { Path } \\
\text { coefficient }\end{array}$ & $\begin{array}{l}\text { Standard } \\
\text { deviation }\end{array}$ & t-statistic & $P$ value & $r^{2}$ \\
\hline Market strategy -> marketing performance & 0.304 & 0.165 & 1.838 & 0.067 & \\
\hline $\begin{array}{l}\text { Marketing mix strategy }->\text { marketing } \\
\text { performance }\end{array}$ & 0.161 & 0.129 & 0.304 & 0.215 & 0.749 \\
\hline Customer value $->$ marketing performance & $0.486^{*}$ & 0.146 & 3.335 & 0.001 & \\
\hline
\end{tabular}

Note: * Significant at $\alpha$ \%

\subsection{Direct Effect of Market Strategy on Marketing Performance}

Table 3 shows that market strategy had no significant effect on marketing performance. Based on the ruling indicator for the number of processed rubber materials sold to customers from the dimension of market formation, auction system marketing did not impose a rule on the volume/number of processed rubber materials to be sold. Factors such as small area of land and erratic weather could affect the performance in producing and selling processed rubber materials. The result shows that the farmer groups never decided on the number of processed rubber materials that should be sold: farmers were free to determine the volume of sales. The absence of a stipulated rule on the number of processed materials to be sold meant that the volume of production produced varied with each sale. This is contrary to the opinion of Orsi, De Noni, Corsi, and Marchisio (2017) that farmer groups need to expand the cumulative amount of production to develop more effective actions to sell products to the market and increase their bargaining power.

\subsection{Direct Effect of Marketing Mix Strategy on Marketing Performance}

Table 3 shows the marketing mix strategy had no significant effect on performance. Purohit et al. (2021) considered physical access to products and services as the main challenge. The inseparability, perishability, and intangibility of services made traditional distribution channels ineffective.

\subsection{Direct Effect of Customer Value on Marketing Performance}

Table 3 shows that customer value had a significant effect on marketing performance. The higher the customer value in the indicator that farmers were satisfied with selling to customers, the higher the marketing performance. Based on the indicator of how satisfied farmers were in selling to customers from the emotional value dimension, farmers' satisfaction in selling was affected by the price that the farmer receives and the availability of access to the customer. The satisfaction felt by farmers in selling materials to customers increased the enthusiasm of farmers in producing quality products.

The result show that several factors led to farmer satisfaction in selling processed rubber materials to customers, including price received by farmers and availability to the customer. If the price received by farmers was high, they would be enthusiastic about producing processed rubber materials in large quantities. If availability was adequate and supported by transportation, it would make it easier for farmers to deliver processed rubber materials.

\subsection{Indirect Effect of Market and Marketing Mix Strategies on Marketing Performance}

The indirect effect of market and marketing mix strategies on marketing performance is shown in Table 4.

Table-4. Use of values for the Sobel test.

\begin{tabular}{|c|c|c|c|c|}
\hline Hypothesis & a & $\mathbf{b}$ & $\mathbf{S a}$ & $\mathbf{S b}$ \\
\hline Market strategy $->$ customer value $->$ marketing performance & 0.203 & 0.370 & 0.022 & 0.085 \\
\hline Marketing mix strategy $->$ customer value $->$ marketing performance & 0.284 & 0.457 & 0.041 & 0.083 \\
\hline
\end{tabular}

\subsection{Indirect Effect of Market Strategy on Marketing Performance}

The hypothesis of the effect of market strategy on marketing performance through customer value used the Sobel test. The values required for the Sobel test are as follows:

$\begin{array}{ll}\mathrm{a} & =0.203 \\ \mathrm{~b} & =0.370 \\ \mathrm{Sa} & =0.022 \\ \mathrm{Sb} & =0.085\end{array}$

The indirect coefficient of market strategy variables on marketing performance is as follows:

$\mathrm{ab}$

$$
\begin{aligned}
& =\mathrm{a} \times \mathrm{b} \\
& =0,203 \times 0,370 \\
& =0,07511
\end{aligned}
$$

The indirect standard error for market strategy variables on marketing performance was obtained as follows:

$$
\begin{aligned}
& S a b=\sqrt{\left.b^{2} \cdot S a^{2}\right)+\left(a^{2} \cdot S b^{2}\right)} \\
& S a b=\sqrt{\left(0,457^{2} \times 0,041^{2}\right)+\left(0,284^{2} \times 0,083^{2}\right)} \\
& S a b=\sqrt{0,00035+0,00055} \\
& S a b=0,019
\end{aligned}
$$


Thus, the $t$-test value was obtained as follows :

$t=\frac{0,075}{0,019}$

$t=3,947$

Based on the results from the processed data, the $t$-count was determined to be $(3.947)>1.96$, which means the hypothesis was accepted. Market strategy through customer value had a significant effect on marketing performance. Thus, higher market strategies mediated by customer value increase marketing performance: namely, if the rubber farmer groups carried out the market strategy properly, this creates customer value, which in turn would increase the marketing performance of smallholder rubber plantations. This is in accordance with the conditions at the research location, where farmer groups that applied the best market strategies, such as maintaining high quality, creating good relationships with customers, using technology, making innovations, increasing knowledge about rubber farming, and providing optimal service so as to create satisfaction and added value in the eyes of customers, thereby increased their marketing performance. Brege and Kindström (2019) have suggested that market strategy acted as a coordinated proactive activity aimed at creating customer value and increasing sales volume and business profits.

\subsection{Indirect Effects of Marketing Mix Strategy on Marketing Performance}

The hypothesis of the effect of the marketing mix strategy on marketing performance through customer value was assessed using the Sobel test. The values required for the Sobel test are as follows:

$\begin{array}{ll}\mathrm{a} & =0.284 \\ \mathrm{~b} & =0.457 \\ \mathrm{Sa} & =0.041 \\ \mathrm{Sb} & =0.083\end{array}$

The indirect coefficient of market strategy variables on marketing performance is as follows:

$\mathrm{ab} \quad=\mathrm{a} \times \mathrm{b}$

$$
\begin{aligned}
& =0,284 \times 0,457 \\
& =0,129788
\end{aligned}
$$

The indirect standard error for market strategy variables on marketing performance was obtained as follows:

$$
\begin{aligned}
& S a b=\sqrt{\left.b^{2} \cdot S a^{2}\right)+\left(a^{2} \cdot S b^{2}\right)} \\
& S a b=\sqrt{\left(0,457^{2} \times 0,041^{2}\right)+\left(0,284^{2} \times 0,083^{2}\right)} \\
& S a b=\sqrt{0,00035+0,00055} \\
& S a b=0,0009
\end{aligned}
$$

The $t$-test value is obtained as follows:

$$
t=\frac{0,129}{0,03}
$$$$
t=4,300
$$

The $t$-count was $(4.300)>1.96$, which means that the marketing mix strategy through customer value had a significant effect on marketing performance. Higher marketing mix strategies mediated by customer value improve marketing performance: namely, if the rubber farmer groups carried out a good marketing mix strategy, it created customer value, which in turn improved the marketing performance of smallholder rubber plantations. According to Purohit et al. (2021), product is a major concern and it is important to acknowledge the customer's perspective when developing it.

\section{CONCLUSION}

Market-based strategies on smallholder rubber plantations in Riau Province during the Covid-19 pandemic have had a significant effect on customer value. The market-based strategies included both market and marketing mix. The market strategy had a dominant effect on the strategy formulation of smallholder rubber plantation farmer groups, where the dimensions of the marketing mix strategy show positive associations and were responded to very well by farmer groups. Better market strategies create superior customer value. Customer value, in turn, was affected by the dominant marketing mix strategy in the dimensions of agricultural product differentiation and product elasticity. Customer value had a direct effect on marketing performance, while market and marketing mix strategies had an indirect effect.

Funding: This study received no specific financial support.

Competing Interests: The authors declare that they have no competing interests.

Acknowledgement: All authors contributed in an equal manner in designing the present research.

Views and opinions expressed in this study are those of the authors views; the Asian Journal of Agriculture and Rural Development shall not be responsible or answerable for any loss, damage, or liability, etc. caused in relation to/arising out of the use of the content. 


\section{REFERENCES}

Bhanot, D., Kathuria, V., \& Das, D. (2020). Can institutional innovations in agri-marketing channels alleviate distress selling? Evidence from India. World Development, 137, 105202. Available at: https://doi.org/10.1016/j.worlddev.2020.105202.

Brege, H., \& Kindström, D. (2019). Exploring proactive market strategies. Industrial Marketing Management, 84, 75-88. Available at: https://doi.org/10.1016/j.indmarman.2019.05.005.

Brenas, S. V. (2019). Nutrient management of immature rubber plantations. Agronomy for Sustainable Development, Springer Verlag/EDP Sciences/INRA, 39(11), 1-21.

Das, S., Deshpande, S., Salvi, S., Goyal, S., \& Bhirud, N. S. (2018). RATAN: A smart business to business (B2B) communicator. Paper presented at the Proceedings - 2018 4th International Conference on Computing, Communication Control and Automation, ICCUBEA.

Deng, R., He, X., Fu, Y., Liu, Y., \& Hu, X. (2019). Analysis on the application strategy of - 4 V $\|$ Marketing mix theory based on the perspective of the perceived value of agricultural products consumer. Advances in Economics,Business and Management Research, 110, 501-504.

Elg, U., Deligonul, S. Z., Ghauri, P. N., Danis, W., \& Tarnovskaya, V. (2012). Market-driving strategy implementation through global supplier relationships. Industrial Marketing Management, 41(6), 919-928. Available at: https://doi.org/10.1016/j.indmarman.2011.11.001.

Grant, A. M., \& Ashford, S. J. (2008). The dynamics of proactivity at work. Research in Organizational Behavior, 28, 3-34. Available at: https://doi.org/10.1016/j.riob.2008.04.002.

Guerrieri, V., Lorenzoni, G., Straub, L., \& Werning, I. (2020). Macroeconomic Implications of Covid-19: Can negative supply shocks cause demand shortages? (Vol. 1050 pp. 1-37). Massachusetts Avenue, Cambridge, MA: National Bureau of Economic Research.

Islam, J. U., Hollebeek, L. D., Rahman, Z., Khan, I., \& Rasool, A. (2019). Customer engagement in the service context: An empirical investigation of the construct, its antecedents and consequences. Journal of Retailing and Consumer Services, 50, 277-285. Available at: https://doi.org/10.1016/j.jretconser.2019.05.018.

Kindström, D., Ottosson, M., \& Carlborg, P. (2018). Unraveling firm-level activities for shaping markets. Industrial Marketing Management, 68, 36-45. Available at: https://doi.org/10.1016/j.indmarman.2017.09.003.

Kotler, P., \& Armstrong, G. (2018). Principles of marketing - Global Edition. In S. Wall (Ed.), Principles of Marketing - Global Edition (16th ed.). England: Pearson Education Limited.

Kwok, L., Tang, Y., \& Yu, B. (2020). The 7 Ps marketing mix of home-sharing services: Mining travelers' online reviews on Airbnb. International Journal of Hospitality Management, 90, $102616 . \quad$ Available at: https://doi.org/10.1016/j.ijhm.2020.102616.

Narver, J. C., Slater, S. F., \& MacLachlan, D. L. (2004). Responsive and proactive market orientation and new-product success. Journal of Product Innovation Management, 21(5), 334-347. Available at: https://doi.org/10.1111/j.07376782.2004.00086.x.

Orsi, L., De Noni, I., Corsi, S., \& Marchisio, L. V. (2017). The role of collective action in leveraging farmers' performances: Lessons from sesame seed farmers' collaboration in eastern Chad. Journal of Rural Studies, 51, 93-104. Available at: https://doi.org/10.1016/j.jrurstud.2017.02.011.

Parker, S. K., Bindl, U. K., \& Strauss, K. (2010). Making things happen: A model of proactive motivation. Journal of Management 36(4), 827-856. Available at: https://doi.org/10.1177/0149206310363732.

Purohit, S., Paul, J., \& Mishra, R. (2021). Rethinking the bottom of the pyramid: Towards a new marketing mix. Journal of Retailing and Consumer Services, 58, 102275. Available at: https://doi.org/10.1016/j.jretconser.2020.102275.

Ranta, V., Keränen, J., \& Aarikka-Stenroos, L. (2019). How B2B suppliers articulate customer value propositions in the circular economy: Four innovation-driven value creation logics. Industrial Marketing Management, 87, 291-305. Available at: https://doi.org/10.1016/j.indmarman.2019.10.007.

Saptutyningsih, E., \& Esty, S. (2020). Quantitative research methods and analytical tools. Mlati, Sleman, Yogyakarta: Gosyen Publishing Jatirejo 588 Sendangadi.

Shimasaki, C. (2014). Biotechnology products and their customers: Developing a successful market strategy. Biotechnology Entrepreneurship, 16, 229-241. Available at: https://doi.org/10.1016/b978-0-12-404730-3.00016-6.

Storbacka, K., \& Nenonen, S. (2015). Learning with the market: Facilitating market innovation. Industrial Marketing Management, 44, 73-82. Available at: https://doi.org/10.1016/j.indmarman.2014.10.009.

Su, C.-W., Liu, L., Tao, R., \& Lobonţ, O.-R. (2019). Do natural rubber price bubbles occur? Agricultural Economics, 65(2), 67-73. Available at: https://doi.org/10.17221/151/2018-agricecon. 